\title{
The Cdc42 effectors Gic1 and Gic2 regulate polarized post-Golgi secretion
}

\author{
Ying Liu', Tianrui Zhang ${ }^{1}$, Dong Sun ${ }^{2}$ and Guangzuo Luo ${ }^{2^{*}}$ (i)
}

\begin{abstract}
Background: Cell polarity refers to spatial difference in morphology, structure, and function within different parts of a single cell, which plays important roles in a wide range of cellular processes. In eukaryotic cells, the small GTPase Cdc42 and phosphatidylinositol 4,5-bisphosphate $\left(\operatorname{Ptdlns}(4,5) \mathrm{P}_{2}\right)$ are critical components for cell polarity and required for polarized exocytosis and cell growth. Previous data showed that the GTPase-interacting components, Gic1 and Gic2, control cell polarity through its binding with $\mathrm{Cdc} 42$ and Ptdlns $(4,5) \mathrm{P}_{2}$ in the plasma membrane in budding yeast. However, whether the Gic proteins regulate polarized exocytosis is unknown.

Results: In this study, we found that Gic2 co-immunoprecipitates with the exocyst complex, suggesting Gic proteins may be involved in exocytosis. Although we could not show the direct interaction between Gic2 and exocyst, we found gic $1 \Delta$ gic $2 \Delta$ are synthetically sick with $\sec 3 \Delta N$. We demonstrated that Gic1 and Gic2 are required for polarized exocytosis in a yeast strain harboring the $\mathrm{N}$-terminal domain deletion of Sec3, which is also known as an effector of Cdc42 GTPase. Gic proteins are required for polarized localization of exocyst, growth, and efficient secretion in sec $3 \Delta \mathrm{N}$ mutant. In addition, we found that the N-terminal domain of both Gic2 and Sec3 share the similar binding sites of Cdc42. Surprisingly, not all the Sec3/Gic binding deficient cdc42 mutants displayed defects of growth and secretion, indicating that disruption of $\mathrm{Cdc} 42$ binding with Gic proteins and Sec3 does not necessarily show secretion defects in cdc42 mutants.

Conclusions: We conclude that Gic1/2 and Sec3 act in parallel to regulate polarized post-Golgi secretion, but this regulation is not solely controlled by their upstream factor $\mathrm{Cdc42}$. Considering that $\mathrm{N}$-terminal domain of Gic2 and Sec3 can bind to both $\mathrm{Cdc} 42$ and Ptdlns $(4,5) \mathrm{P}_{2}$, the regulation of Gic protein and Sec3 on polarized secretion may also be controlled by Ptdlns $(4,5) \mathrm{P}_{2}$. Further experiments need to be performed to test this hypothesis. Our findings provide important clues for understanding the molecular mechanism of cell polarity establishment in eukaryotic cells.
\end{abstract}

Keywords: Cdc42, Gic proteins, Sec3, Exocytosis, Exocyst

\section{Introduction}

Cell polarity is a common feature for most if not all eukaryotes. It is essential for many processes such as cell growth, differentiation, and morphogenesis, which rely on successful implementation of polarized secretion [1-4]. Previous studies indicated that Cdc42 controls polarized post-Golgi secretion [5-7]. A key downstream effector of Cdc42 is the exocyst [7-10], which is an evolutionarily conserved octameric protein complex that

\footnotetext{
*Correspondence: gzluo@cmu.edu.cn

${ }^{2}$ Institute of Translational Medicine, China Medical University,

Shenyang 110122, China

Full list of author information is available at the end of the article
}

mediates the tethering of post-Golgi secretory vesicles to the plasma membrane prior to fusion [11-14]. The exocyst subunits are localized to sites of active secretion and cell surface expansion. In the budding yeast, the exocyst is localized to the bud tip during early stages of daughter cell growth, and the mother-daughter cell junction ("neck") during cytokinesis. The exocyst subunits Sec3 and Exo70 directly interact with $\operatorname{PtdIns}(4,5) \mathrm{P}_{2}$ and the Rho family of GTPases at the plasma membrane [9, $10,15-21]$. The assembly of the exocyst complex mediates the tethering of the secretory vesicles to the plasma membrane for exocytosis [22-25]. Cdc42, in its GTPbound state, interacts with the N-terminus of Sec3 [7, 8]. 
Disrupting the Sec3-Cdc42 interaction leads to synthetic defects in secretion in a background where the cells are mutated in another exocyst subunit, Exo70, which was also shown to interact with Cdc42 $[9,10,17,18]$.

The GTPase-interacting components Gic1 and Gic2, also called Gic proteins, share 39\% identity and 54\% similarity in protein sequence, and play critical role for establishment of cell polarity. They are involved in initiation of budding and cellular polarization through interacting with Cdc42 via the Cdc42/Rac-interactive binding (CRIB) domain and with $\mathrm{PI}(4,5) \mathrm{P}_{2}$ via a polybasic region $[10,26-30]$. Although it has been shown that the lethality of the sec $3 \Delta N$ exo $70-38$ double mutant can be rescued by adding the $\mathrm{N}$ terminus of Gic2 to $\sec 3 \Delta N$ [10], it is not clear whether Gic proteins is involved in polarized secretion.

In this study, we find that Gic2 physically interacts with exocyst complex, and Gic proteins are required for polarized exocytosis in a mutant strain harboring the deletion of Sec3N-terminal domain. But the disruption of Cdc42 binding with Gic proteins and Sec3 does not necessarily show secretion defects and growth inhibition in $c d c 42$ mutants. Our data suggests that Gic proteins may regulate polarized secretion by the coordination of both Cdc42 and PtdIns $(4,5) \mathrm{P}_{2}$.

\section{Results}

Gic2 co-immunoprecipitates with the exocyst complex

Because both Sec3 and Gic proteins bind to Cdc42 via the Cdc42/Rac-interactive binding (CRIB) domain and with $\mathrm{PI}(4,5) \mathrm{P}_{2}$ via a polybasic region $[10,26,27,29,30]$, and lethality of the $\sec 3 \Delta N$ exo70-38 double mutant can be rescued by adding the $\mathrm{N}$ terminus of Gic 2 to $\sec 3 \Delta N$ [10], we speculate that Gic protein may be involved in targeting the exocyst complex to the polarized sites as Sec3N-terminal domain does. To test this hypothesis, we first examined whether Gic1 and/or Gic2 physically associate exocyst in the cells. GFP-tagged Gic2 was expressed in wild type yeast strain, in which the endogenous Sec8 or Exo84 was tagged with the myc epitope by chromosomal integration. Immunoprecipitation was performed using an anti-GFP antibody to detect the association of Gic2 with the exocyst complex. As shown in Fig. 1, the exocyst complex, as represented by the myc-tagged Sec8 and Exo84, co-immunoprecipitated with Gic2-GFP. This result suggests that Gic proteins are physically associated with exocyst complex and may be involved in exocytosis.

\section{Gic proteins are required for polarized localization of exocyst in $\sec 3 \Delta N$ mutant}

It was reported that Gic1 and Gic2 are localized specifically to the bud tip, and their localization requires $\mathrm{Cdc} 42$ and PtdIns $(4,5) \mathrm{P}_{2}$ binding, but is mostly independent of

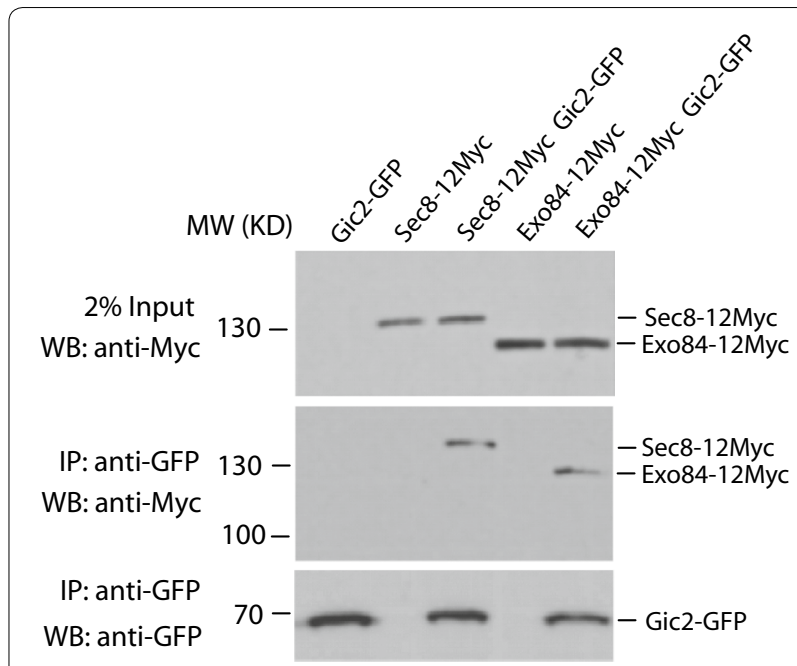

Fig. 1 The exocyst complex co-immunoprecipitates with Gic2. Yeast strains expressing Sec8-myc or Exo84-myc were transformed with GFP-tagged Gic2. Cells were immunoprecipitated with polyclonal anti-GFP antibody, and probed with anti-myc monoclonal antibody or anti-GFP monoclonal antibody in western blot. Top panel

shows the full-length Sec8-myc and Exo84-myc in the lysates. The middle panel shows that Sec8-myc and Exo84-myc were co-immunoprecipitated in cells expressing GFP-tagged Gic2, but not in cells expressing un-tagged Gic2. The bottom panel shows the Gic2-GFP immunoprecipitated by the anti-GFP polyclonal antibody. GFP-tagged Gic2 and cells expressing un-tagged Sec8 or Exo84 were used as negative control. The representative results from three independent experiments are shown

actin $[26-28,30]$. Since Gic proteins control cell polarity and Gic2 physically interacts with exocyst complex, we wonder whether Gic1 and Gic2 regulate polarized localization of exocyst as Sec3N-terminal domain does. The $\sec 3 \Delta N$ mutant protein was not able to bind to Cdc42 and $\mathrm{PI}(4,5) \mathrm{P}_{2}$ in vitro, but the exocyst subunits were polarized to bud tip in this mutant strain [10]. We examined the localization of C-terminal green fluorescent protein (GFP) tagged exocyst subunits, Sec5, Sec8, Exo70 and Exo84, in the strains of wild type, sec $3 \Delta N$, gic $1 \Delta$ gic $2 \Delta$ and gic $1 \Delta$ gic $2 \Delta \sec 3 \Delta N$. As shown in Fig. 2, the exocyst subunits were polarized to bud tip in gic1 $\Delta$ gic $2 \Delta$ and $\sec 3 \Delta N$, which is similar to that in wild type cells. In gic1 $\Delta$ gic $2 \Delta \sec 3 \Delta N$ triple mutant cells, however, most exocyst proteins were either depolarized or diffused inside the cells. We also examined the actin pattern in these mutant strains, and found that actin organization is mostly polarized in these mutants at $25^{\circ} \mathrm{C}$ (Additional file 1: Figure $\mathrm{S} 1$ ). In addition, the assembly of the exocyst complex was unaffected in sec $3 \Delta N$, gic1 1 gic $2 \Delta$, and $\sec 3 \Delta N$ gic $1 \Delta$ gic $2 \Delta$ triple mutant (Additional file 2: Figure S2). These data suggest that Gic2 and its a paralog, Gic1, may function in parallel with Sec3 for exocyst targeting to the polarized growth sites. 


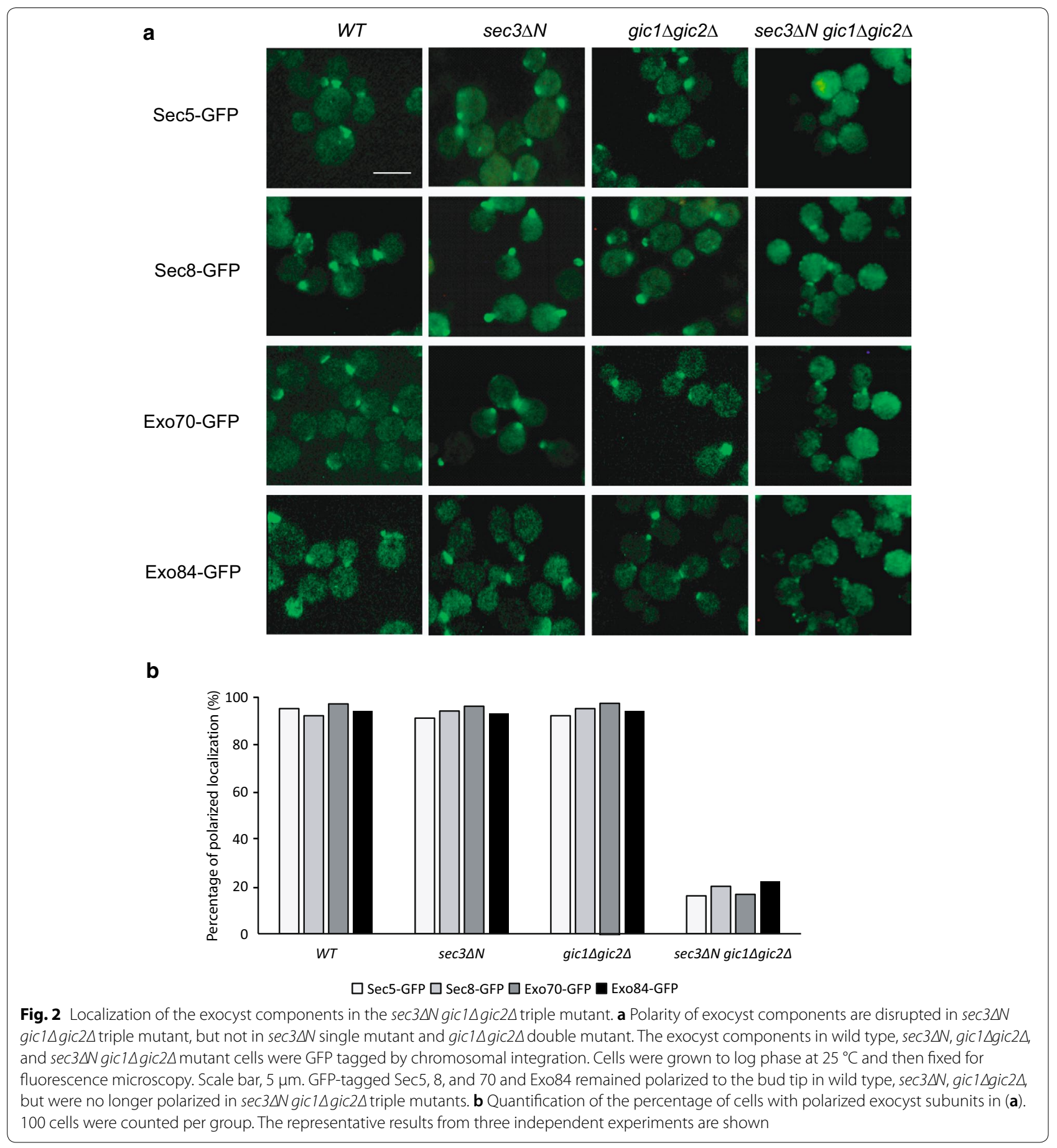

\section{Deletion of the Gic proteins causes growth and secretion defects in $\sec 3 \Delta N$ mutant}

Because Gic proteins are required for polarized localization of exocyst in $\sec 3 \Delta N$ mutant, we speculate that Gic2 and its a paralog, Gic1, may function in parallel with Sec3 for post-Golgi secretion, and a strain with deletion of Gic1 and Gic2 would have synthetic growth effect with $\sec 3 \Delta N$ mutant. To test this hypothesis, we deleted GIC1 and GIC2 either alone or in a sec $3 \Delta N$ mutant background yeast strain. As shown in Fig. 3, this combination resulted in a more severe growth defect than either gic $1 \Delta$ gic $2 \Delta$ or $\sec 3 \Delta N$ alone at $25^{\circ} \mathrm{C}, 32{ }^{\circ} \mathrm{C}, 35^{\circ} \mathrm{C}$ and $37^{\circ} \mathrm{C}$. This result suggests that Gic1 and Gic2 may be involved in regulating exocyst complex in a pathway parallel to Sec3. 


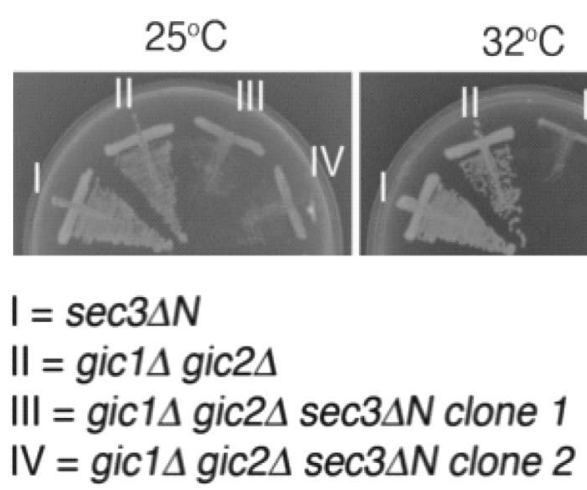

Fig. 3 The gic $1 \triangle$ gic $2 \Delta$ double mutant has a synthetic growth defect with the sec $3 \Delta \mathrm{V}$ mutant. The gic $1 \Delta$ gic $2 \Delta$ double mutants were transformed

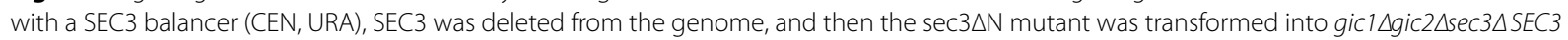
cells. The transformants were streaked onto 5-FOA plates to select for the loss of the wild type SEC3 balancer. The resulting strains were streaked out

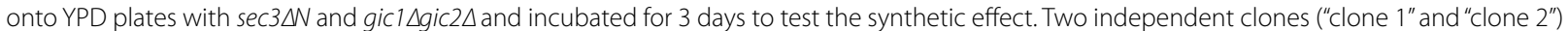
were tested. The $\sec 3 \Delta \mathrm{N}$ gic $1 \Delta$ gic $2 \Delta$ strains show severe growth defect at $25^{\circ} \mathrm{C}$, and a loss of viability at elevated temperatures. As controls, sec $3 \Delta \mathrm{N}$ is normal in growth at all the temperatures tested; the gic $1 \Delta$ gic $2 \Delta$ mutant has normal growth at $25^{\circ} \mathrm{C}$, has slower growth at higher temperatures, and cannot survive at $37^{\circ} \mathrm{C}$. The representative results from three independent experiments are shown

To determine whether these mutations cause secretion defects, we have analyzed the secretion of two cargoes, the cell wall endo-glucanase Bgl2 and the periplasmic enzyme invertase, which are well-characterized markers for the two major classes of post-Golgi vesicles that deliver proteins to the cell surface [31]. As shown in Fig. 4a, Bgl2 accumulation in cytosol (internal) was minimal in the $\sec 3 \Delta N$ and gic1 $\Delta$ gic $2 \Delta$ double mutant at $25{ }^{\circ} \mathrm{C}$, and a small amount of Bgl2 was accumulated in the $\sec 3 \Delta N$ gic1 $\Delta$ gic $2 \Delta$ triple mutant. After shifting to $37{ }^{\circ} \mathrm{C}$ for $2 \mathrm{~h}$, although the $\sec 3 \Delta N$ and gic1 $\Delta$ gic $2 \Delta$ double mutants still did not accumulated Bgl2 protein inside cytosol, the $\sec 3 \Delta N$ gic $1 \Delta$ gic $2 \Delta$ triple mutant showed a pronounced amount of $\mathrm{Bgl} 2$ accumulation. As a control, the sec10-2 cells did not accumulate Bgl2 at $25{ }^{\circ} \mathrm{C}$, but accumulate $\mathrm{Bgl} 2$ at $37{ }^{\circ} \mathrm{C}$. These results indicate that combining $\sec 3 \Delta N$ with gic1 $\Delta$ gic $2 \Delta$ greatly aggravates the Bgl2 secretion defects.

We also examined the secretion of the periplasmic enzyme invertase in the $\sec 3 \Delta N$, gic1 $\Delta$ gic $2 \Delta$ double mutant, and sec $3 \Delta N$ gic $1 \Delta$ gic $2 \Delta$ triple mutant. As shown in Fig. $4 \mathrm{~b}$, at both $25^{\circ} \mathrm{C}$ and $37^{\circ} \mathrm{C}$, the wild type, sec $3 \Delta N$ or gic $1 \Delta$ gic $2 \Delta$ mutant cells secreted $>85 \%$ of the total invertase outside of cytosol. However, only about $62 \%$ of invertase in sec $3 \Delta N$ gic1 $1 \Delta$ gic $2 \Delta$ triple mutant cells was secreted outside at $25{ }^{\circ} \mathrm{C}$. After a 2 -h shift to $37{ }^{\circ} \mathrm{C}$, the triple mutant cells only secreted about $30 \%$ of the total invertase.

To examine whether exocytic vesicles are accumulated in $\sec 3 \Delta N$, gic $1 \Delta$ gic $2 \Delta$ double mutant, and $\sec 3 \Delta N$ gic $1 \Delta$ gic $2 \Delta$ triple mutant, we performed thin-section electron microscopy on these mutants. As shown in Fig. 4c, $\mathrm{d}$, at $25^{\circ} \mathrm{C}$, there were less than 10 vesicles accumulated in $\sec 3 \Delta N$ and gic1 $\Delta$ gic $2 \Delta$ double mutant, whereas the $\sec 3 \Delta N$ gic1 $\Delta$ gic $2 \Delta$ triple mutant accumulated about $62.9 \pm 9$ vesicles/section vesicles. These results clearly show that Sec3 and Gic1/2 function at parallel to regulate exocytosis.

\section{Interaction between Gic2 and Cdc42 mutants defective in Sec3-binding is reduced}

Since Gic proteins and Sec3 are downstream effectors of Cdc42, we want to know whether the regulation of Gic proteins and Sec3 on polarized exocytosis is under the control of Cdc42.

The exocyst subunit Sec3 was proposed to be a landmark on the plasma membrane for exocytosis $[6,15]$, and is a direct downstream effector of Cdc42 [7, 10]. Sec3 interacts with $\mathrm{Cdc} 42$ through a $\mathrm{PH}$ domain-like region at its N-terminus [8, 10, 32]. Although some Sec3-binding deficient cdc42 mutants were reported, the binding sites inside Cdc42 and Sec3 is unknown. Besides Cdc42, Sec3 also interacts with Rho1 [16]. Both Cdc42 and Rho1 belong to the Rho family of small GTPases. Rho1 and Cdc42 in Saccharomyces cerevisiae share a high degree of sequence similarity. The crystal structure of the N-terminus of Sec3 ("Sec3N") alone and the Sec3NRho1 complex were resolved [8, 32]. The region of Rho1 that interacts with $\mathrm{Sec} 3 \mathrm{~N}$ is almost identical to a corresponding region of $\mathrm{Cdc} 42$ (Fig. 5a), consistent with the previous finding that $\mathrm{Cdc} 42$ and Rho1 compete in their binding to Sec3 [7]. Yamashita et al. determined that the mutations in the Switch I and Switch II regions (V43A, F44A, Q68A, Y71A and R73A) in Rho1 would disrupt its 
a

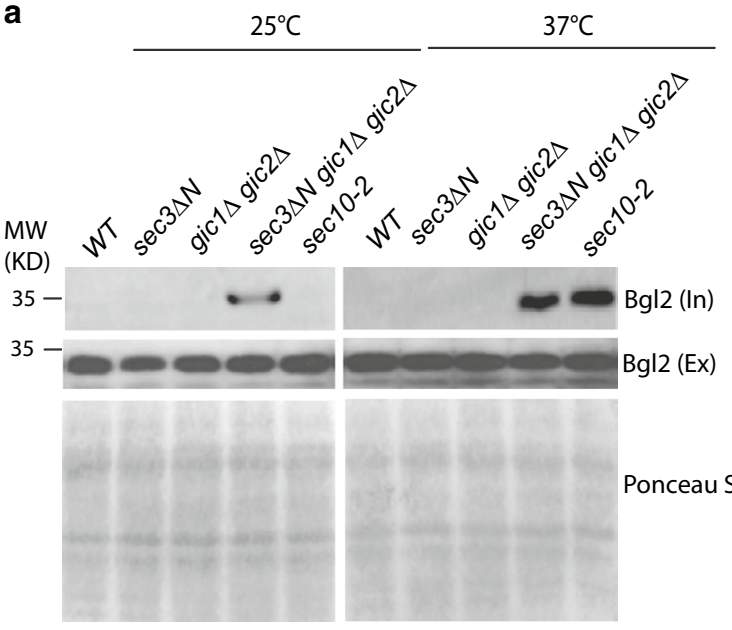

b

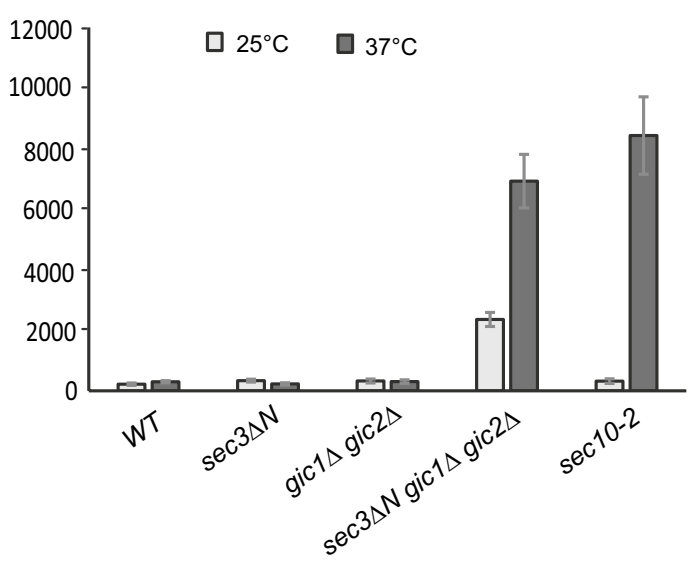

C

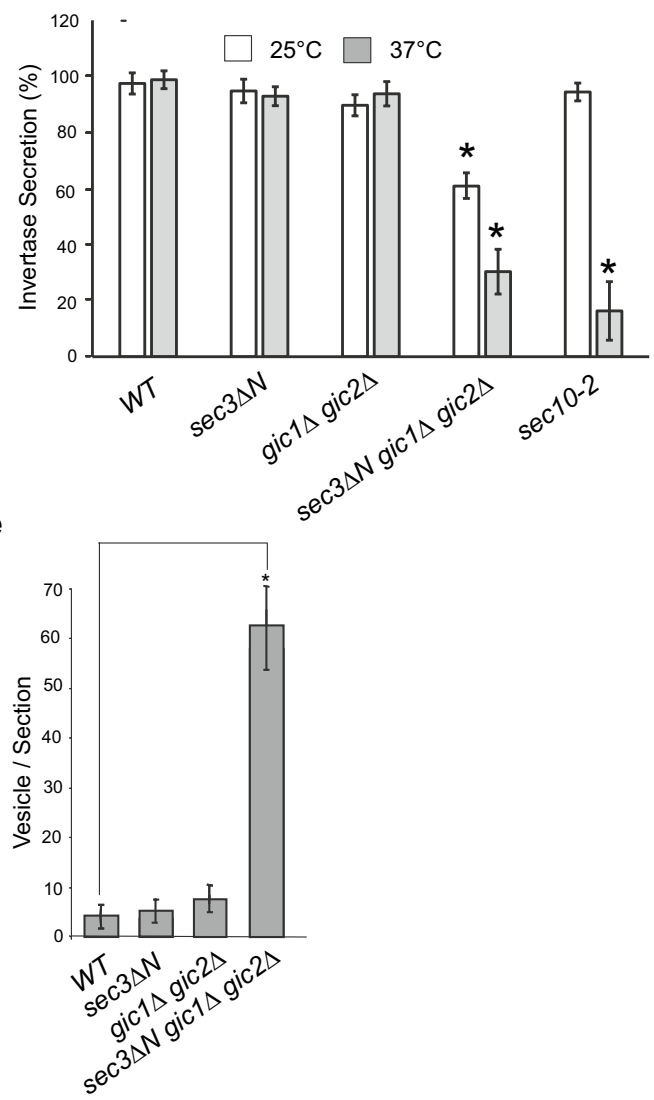

\section{d}
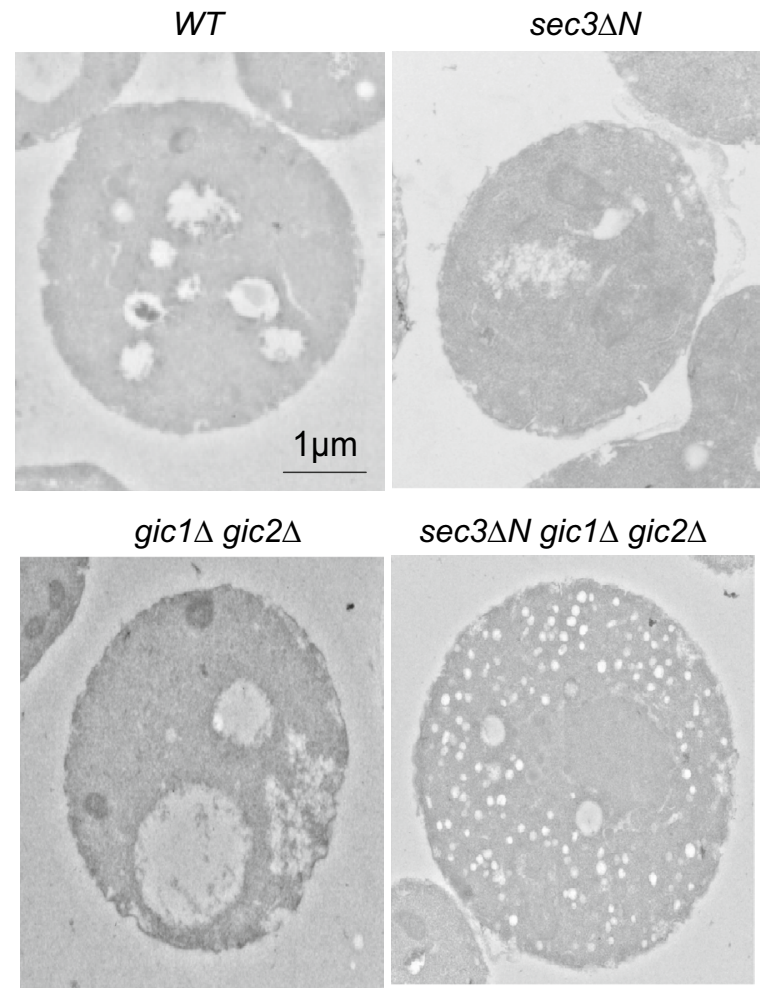

$\sec 3 \Delta N$ gic $1 \Delta$ gic $2 \Delta$

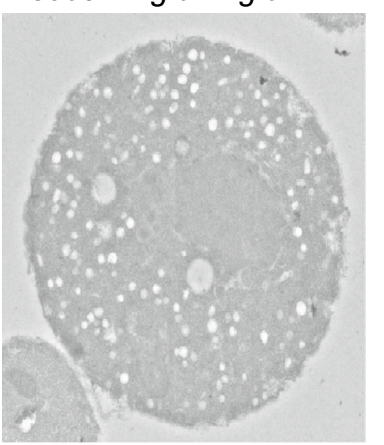

Fig. 4 Deletion of the Gic1 and Gic2 in sec3 mutant cells defects in exocytosis. a sec3 $\Delta$ Ngic $1 \Delta$ gic $2 \Delta$ triple mutant cells have Bgl2 secretion defects at $25^{\circ} \mathrm{C}$, with a significantly greater defect at $37^{\circ} \mathrm{C}$. Single, double, and triple mutants, as well as sec $10-2$ mutants that are known to have Bgl2 secretion defects at $37^{\circ} \mathrm{C}$, were grown in YPD at $25^{\circ} \mathrm{C}$ to early log phase and then grown at $25^{\circ} \mathrm{C}$ or shifted to $37^{\circ} \mathrm{C}$ for 90 min. The internal and external pools of Bgl2 are detected by Western blot using anti-Bgl2 antibody, and total protein on the PVDF membrane stained with Ponceau S was used as a loading control. b Quantification of the amounts of Bgl2 accumulation in cytosol in (a). Error bars represent standard deviation. $\mathrm{n}=3$. c sec $3 \Delta$ Ngic $1 \Delta$ gic $2 \Delta$ triple mutant cells have invertase secretion defects. Single, double, and triple mutants, as well as sec10-2 mutants were grown in YPD at $25^{\circ} \mathrm{C}$ to early log phase and then grown at $25^{\circ} \mathrm{C}$ or shifted to $37^{\circ} \mathrm{C}$ for $90 \mathrm{~min}$ and the invertase secretion of each strain was measured. ${ }^{*} p<0.01$. Error bars represent standard deviation. $n=3$. $\mathbf{d}$ Triple mutants accumulated a large number of vesicles. Single, double and triple mutants were grown in YPD at $25^{\circ} \mathrm{C}$ to early log phase. Cells were fixed and imaged using an electron microscope. e Quantification of images in (d). 10 cells were counted per group, bars represent standard error. ${ }^{*} p<0.05$, student's t-test 
Cdc42p --MQT-----LKCVVVGDGAVGKTCLLISYTTNQFPADYVPTVFDNYAVTVMIGDEPYTL 53 Rho1p MSQQVGNSIRRKLVIVGDGACGKTCLLIVFSKGQFPEVYVPTVFENYVADVEVDGRRVEL 60

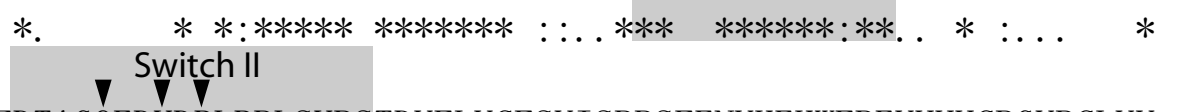

Cdc42p GLFDTAGQEDYDRLRPLSYPSTDVFLVCFSVISPPSFENVKEKWFPEVHHHCPGVPCLVV 113 Rho1p ALWDTAGQEDYDRLRPLSYPDSNVVLICFSIDLPDSLENVQEKWIAEVLHFCQGVPIILV 120

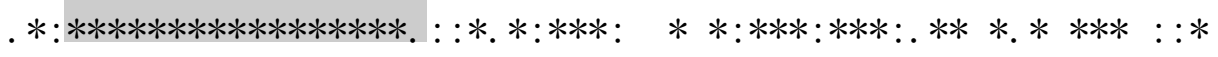

Cdc42p GTQIDLRDDKVIIEKLQRQRLRPITSEQGSRLARELKAVKYVECSALTQRGLKNVFDEAI 173 Rho1p GCKVDLRNDPQTIEQLRQEGQQPVTSQEGQSVADQIGATGYYECSAKTGYGVREVFEAAT 180 $*:: * * *: * \quad * *: *:::$ : $* * *:: * .::: *^{*} * * * * * * *::: * *: *$

Cdc42p VAALEP------------PVIKKSKKCAIL 191

Rho1p RASLMGKSKTNGKAKKNTTEKKKKKCVLL 209

$*: *$

b

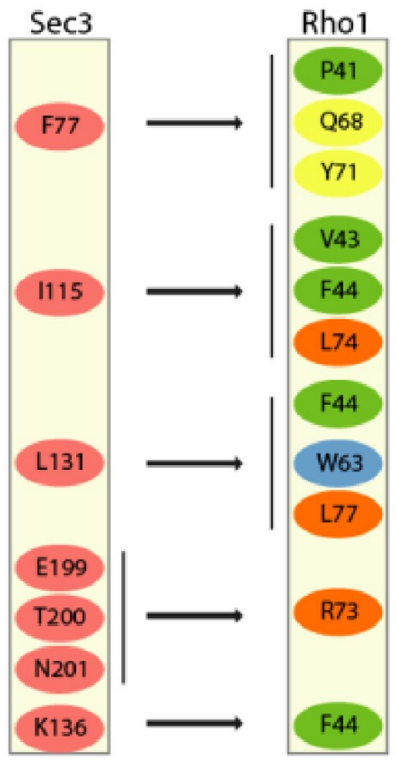

.. ***. ***. :* 
binding to Sec3 [32]. Based on the Sec3-binding region of Rho1 (Fig. 5b), we mutated the corresponding amino acids in Cdc42 to alanine by site-directed mutagenesis. Five $c d c 42$ mutants were made in this study to confirm its binding to Sec3: $c d c 42-301$ (V36A), $c d c 42-302$ (V36A F37A), $c d c 42-303(\mathrm{Q} 61 \mathrm{~A}), c d c 42-304(\mathrm{Y} 64 \mathrm{~A})$ and $c d c 42-$ 305 (Y64A R66A). Our in vitro binding assay showed that these $c d c 42$ mutants were defective in binding to GSTSec3N (a.a.71-241) (Fig. 5c).

The N-terminus of Gic2 contains the classic Cdc42/ Rac1 interactive binding (CRIB) domain [26, 27]. Because both Sec3 and Gic1/2 are Cdc42 downstream effectors and lethality of the $\sec 3 \Delta N$ exo $70-38$ double mutant can be rescued by adding the $\mathrm{N}$ terminus of Gic 2 to $\sec 3 \Delta N$ [10], we tested whether any of the $c d c 42$ mutants defective in Sec3N-binding exhibited altered binding to Gic2. We chose to focus on Gic2 because it was reported that, like Sec3, Gic2 can associate with the plasma membrane through binding to $\mathrm{Cdc} 42$ or directly binding to $\operatorname{PtdIns}(4,5) \mathrm{P}_{2}$, and these associations are important for polarized cell growth [30]. The in vitro binding assay of cdc42 mutants was performed using GST-tagged Gic2N (amino acids 1-155), which contains its Cdc42-interacting domain [30]. As shown in Fig. 5d, except for $c d c 42-$ 302 , the binding of GST-Gic2N to the other four $c d c 42$ mutants decreased dramatically. These results suggest that the binding sites of Cdc42 in Gic2 is very similar to Sec3.

\section{Sec3-binding deficient Cdc42 mutants displayed different characteristics at growth and secretion}

To evaluate the physiological role of the interaction of Cdc42 with both Sec3 and Gic proteins, we have expressed the Sec3-binding deficient Cdc42 mutants in Saccharomyces cerevisiae under control of the endogenous Cdc42 promoter. The growth of the mutant cells was examined on YPD plates at $25^{\circ} \mathrm{C}$ or $37^{\circ} \mathrm{C}$ (Fig. 6a). The five $c d c 42$ mutants grew well as wild type cells at $25{ }^{\circ} \mathrm{C}$. At $37{ }^{\circ} \mathrm{C}$, however, $c d c 42-303$ and $c d c 42-305$ mutants show growth defects, while the growth rate of the other three $c d c 42$ mutants is similar to wild type strain.

To examine whether the growth defect was an outcome of secretion inhibition in $c d c 42-303$ and $c d c 42-$ 305 mutants, we examined the secretion of the cell wall enzyme Bgl2 and the periplasmic enzyme invertase. The $c d c 42-303$ and $c d c 42-305$ cells showed mild defect of $\mathrm{Bgl} 2$ secretion at $25{ }^{\circ} \mathrm{C}$, and the secretion in these mutants was seriously inhibited at $37^{\circ} \mathrm{C}$ (Fig. 6b). However, only $c d c 42-303$ but not $c d c 42-305$ showed a partial but statistically significant invertase secretion defect at both $25{ }^{\circ} \mathrm{C}$ and $37{ }^{\circ} \mathrm{C}$ (Fig. 6c). It is not surprising that $\mathrm{Cdc} 42$ may regulate only one type of exocytic cargo under certain condition. Adamo et al. [5] observed that the $c d c 42-6$ mutant had a more profound defect in Bgl2 secretion than invertase. Our results are consistent with this observation.

To further confirm the secretion defects in $c d c 42-303$ and $c d c 42-305$ mutants, the two mutants were examined by electron microscopy. Post-Golgi vesicles, which are typically $80-100 \mathrm{~nm}$ in diameter, accumulated about 127 and 155 vesicles per section in $c d c 42-303$ and $c d c 42$ 305 mutants at $37{ }^{\circ} \mathrm{C}$, respectively (Fig. 6d, e). These results indicate the secretion in $c d c 42-303$ and $c d c 42-305$ mutants was inhibited.

Taken together, the disruption of Cdc42 with Sec3 and Gic1/2 does not necessarily lead to growth and secretion defects, which means other factor, such as $\mathrm{PI}(4,5) \mathrm{P}_{2}$, may also controls the regulation of Gic proteins on polarized secretion. The different growth and secretion characteristics among $d c 42$ mutants in this study also suggests that, except for Sec3 and Gic1/2, other Cdc42 effectors may also involved in polarized secretion.

\section{Discussion}

In this study, we have examined the role of the two Cdc42 effectors, Gic1 and Gic2, in polarized secretion. We found that Gic2 are associated with exocyst complex (Fig. 1). Although we could not show the direct interaction between Gic2 and exocyst components under our experimental conditions, we found that gic1 1 gic $2 \Delta$ double mutant is synthetically sick with sec $3 \Delta N$ single mutant and regulates cell gowth and exocytic secretion. Gic proteins regulate polarized secretion by targeting the tethering complex to bud tip of yeast cells (Figs. 2, 4). However, although both Gic proteins and Sec3 are the effectors of Cdc42, disrupting the physical interaction of Cdc42 with these effectors does not necessarily show growth and secretion defect (Fig. 6), indicating Cdc42 is not the only upstream regulator of Gic1/2 and Sec3 who control the polarized secretion.

Although Gic1/2 and Sec3 are considered the downstream effectors of Cdc42, they can also function in the upstream of Cdc42. It was reported that Gic1 and Gic2 may stabilize the Cdc42 effector complex at the bud site and regulate initiation of budding [29]. Orlando et al. reported that transportation of Cdc42 to the bud site depends on the exocytic pathway in yeast [33]. Because Sec3 is the landmark of exocytic secretion [15], it may also regulates polarization of $\mathrm{Cdc} 42$. According to these data, it is possible that Gic1 and Gic2 may also regulate polarized exocytic secretion through Cdc42.

Zhang et al. [7, 10] found that Sec3N terminal domain can bind to both Cdc42 and PtdIns $(4,5) \mathrm{P}_{2}$. The Cdc42binding domain in Sec3N-terminus is adjacent to the $\operatorname{PtdIns}(4,5) \mathrm{P}_{2}$ binding region, and the interaction of 
a

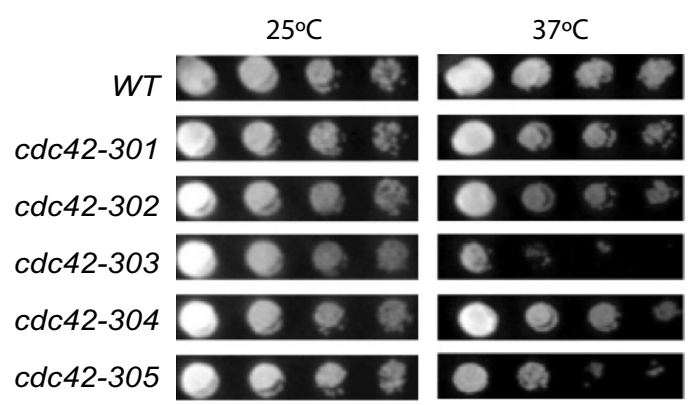

C

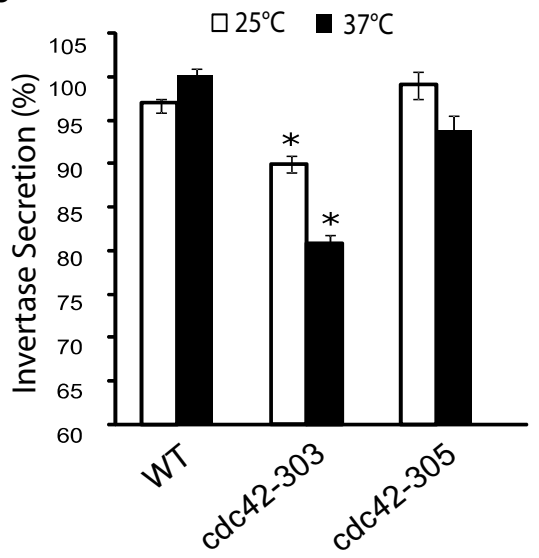

d

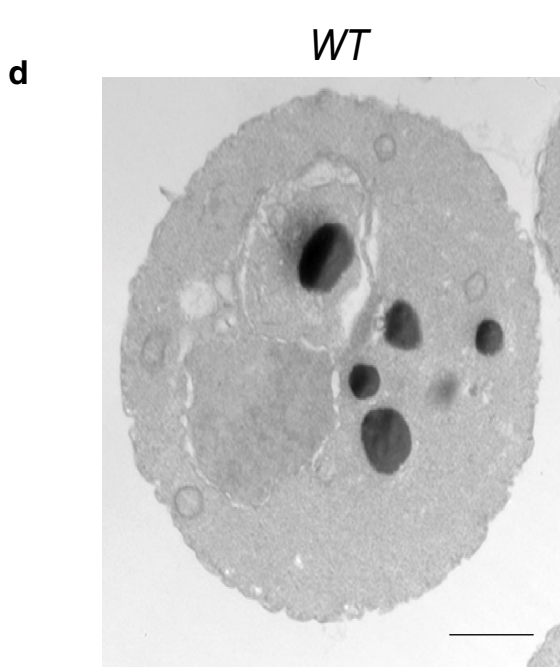

e

\section{b}
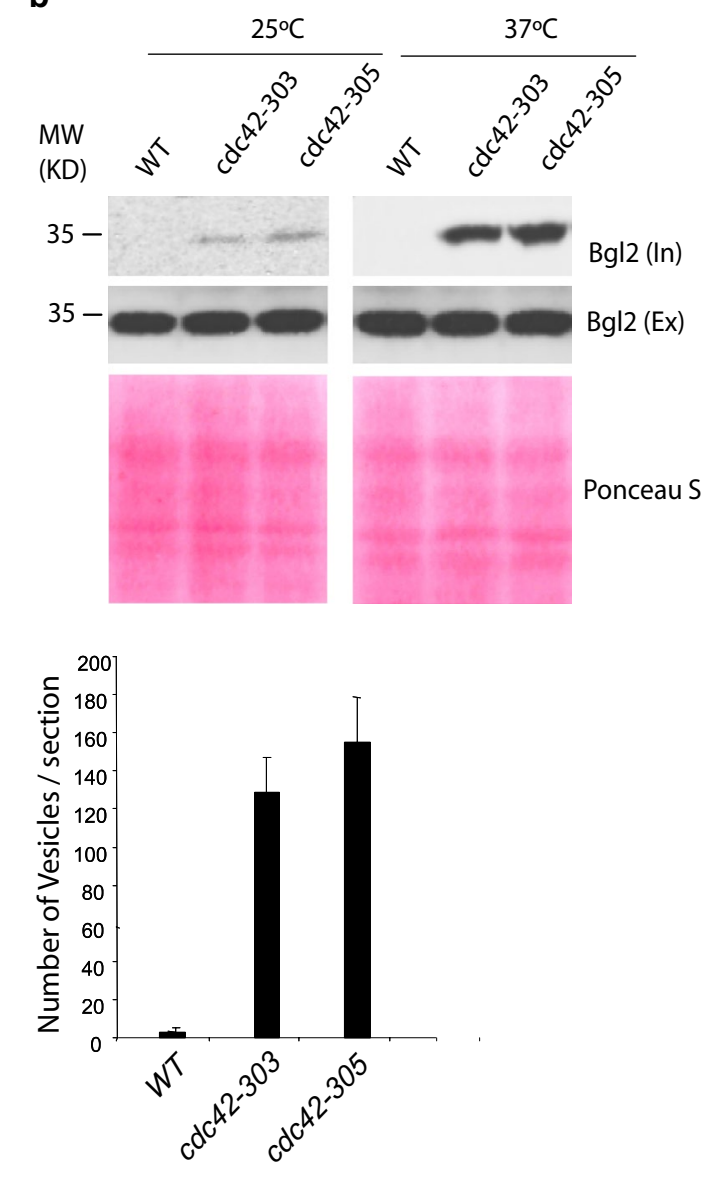

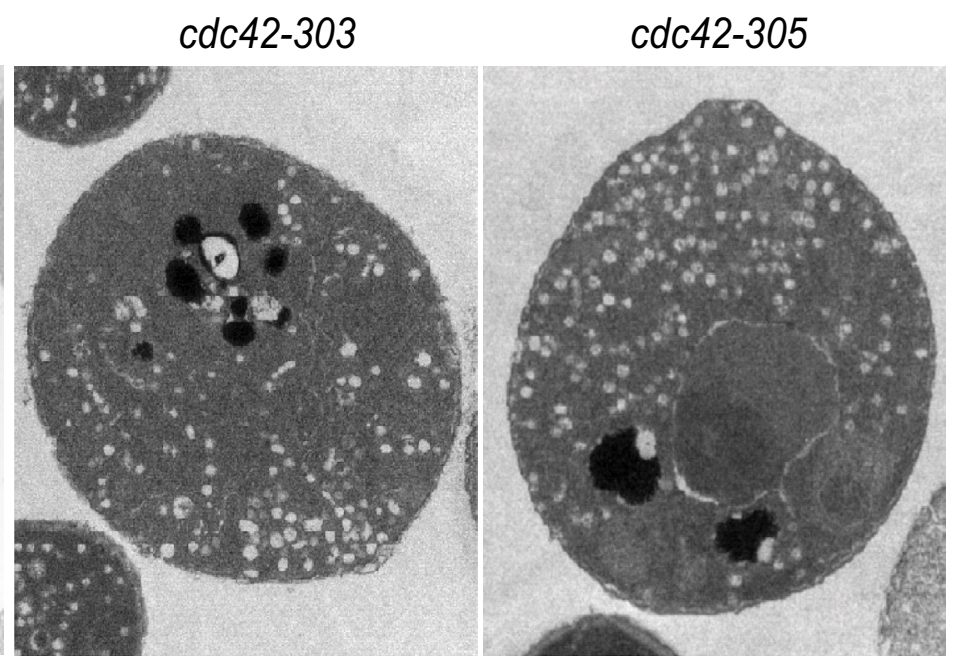

Fig. 6 Growth and Secretion defects in cdc42 mutant alleles. a Temperature-dependent growth of cdc42 mutants. Equal densities of wild-type or $c d c 42$ mutant cells were spotted in tenfold serial dilutions from left to right on YPD plates and incubated at $25^{\circ} \mathrm{C}$ or $37^{\circ} \mathrm{C} . c d c 42-303$ and $c d c 42-305$ had severe growth defects at $37^{\circ} \mathrm{C} . \mathbf{b} c d c 42-303$ and $c d c 42-305$ have Bgl2 secretion defects at both $25^{\circ} \mathrm{C}$ and $37^{\circ} \mathrm{C}$. Wild-type and cdc42 mutants are grown in YPD at $25^{\circ} \mathrm{C}$ to early log phase and then grown at $25^{\circ} \mathrm{C}$ or shifted to $37^{\circ} \mathrm{C}$ for $90 \mathrm{~min}$. The internal and external pools of Bgl2 are detected by Western blot using anti-Bgl2p antibody. $\mathbf{c} c d c 42-303$ has invertase secretion defects at both $25^{\circ} \mathrm{C}$ and $37^{\circ} \mathrm{C}$. ${ }^{*} \mathrm{p}<0.001$ d Thin-section transmission EM of wild type, $c d c 42-303$ and $c d c 42-305$. Cells were grown at $25^{\circ} \mathrm{C}$ and shifted at $37^{\circ} \mathrm{C}$ for 90 min. e Quantification of cells who have large amount of secretion vesicles in GY3670 (cdc42-303) and GY3672 (cdc42-305). 10 cells were counted for each group. Error bars represent standard deviations. The representative results from three independent experiments are shown 
Sec3N-terminus with both $\mathrm{Cdc} 42$ and $\operatorname{PtdIns}(4,5) \mathrm{P}_{2}$ are important for Sec3 function. Yamashita et al. [32] also found that $\sec 3$ mutants deficient in the binding of either Rho1 or PtdIns $(4,5) \mathrm{P}_{2}$ can still be localized to the bud tip even in the presence of Latrunculin $B$, which disrupts the actin microfilament cytoskeleton, while the sec3 mutants deficient in the binding of both Rho1 and PtdIns $(4,5) \mathrm{P} 2$ are almost completely depolarized in the presence of Latrunculin $B$. These results suggest that both Rho GTPase and PtdIns(4,5)P2 can act as receptors for the exocyst complex in a complementary fashion. Gic proteins are considered to be targeted to the bud tip and plays an important role in early bud formation in yeast. The GTP-bound Cdc42 interacts with Gic2 through the Cdc42/Rac interactive binding domain located at the $\mathrm{N}$ terminus of Gic2 and activates Gic2 during bud emergence [26, 27]. Orlando et al. [30] have identified a polybasic region in Gic2 adjacent to the Cdc42/Rac interactive binding domain, which directly interacts with PtdIns $(4,5) \mathrm{P}_{2}$ in the plasma membrane. This physical interaction is also necessary for the polarized localization of Gic2 protein to the bud tip and is important for the function of Gic2 in cell polarity. These facts indicate that $\operatorname{PtdIns}(4,5) \mathrm{P}_{2}$ and Cdc42 act in concert to regulate polarized localization and function of Gic2 during polarized cell growth in the budding yeast. Based on these previous reports and the results shown in our study, we speculate that either the Cdc42-Sec3/Gic interaction or $\operatorname{PtdIns}(4,5)$ $\mathrm{P}_{2}$-Sec3/Gic interaction can targeting the exocyst complex to the polarized growth sites, which explains the result that three Sec3-binding deficient $c d c 42$ mutants did not show growth defect in Fig. 6, though these $c d c 42$ mutants can not bind to Sec3 and/or Gic2.

Cdc42, the highly conserved small GTPase in eukaryotic organisms, mediates extracellular signals, triggering changes in transcription and in the actin cytoskeleton organization. Dozens of proteins have been found to act downstream of Cdc42, such as members of the PAK, WASP/WAVE, formin, lipid-kinase, IQGAP and NADPH oxidase families [34]. Although the disruption of interaction of Cdc42-Sec3/Gic is not sufficient to trigger secretion inhibition, these Sec3/Gic-binding deficient $c d c 42$ mutants may also be defective in interaction with other effectors. It is possible that the interaction of Cdc42 with other effectors are also destroyed in the two $c d c 42$ mutants, $c d c 42-303$ and $c d c 42-305$. But it is unlikely that the ATP loading capacity of these mutants is the main reason for the binding defect because no interaction was detected between cdc42 mutants and Sec3, and neither GDP nor GTP affected the binding of Sec3 to all five mutants (Additional file 3: Figure S3). In addition, even if the ATP loading capacity of some $c d c 42$ mutants is defective, for example $c d c 42-303$ and $c d c 42-305$, this effect on the binding of Cdc42 to Sec3 and Gic1/2 is generic to all the downstream effectors, not specific to Sec3 and Gic1/2.

To exclude the possibility that actin, instead of Gic proteins, are responsible for the secretion defects in gic $1 \Delta$ gic $2 \Delta \sec 3 \Delta N$ triple mutant cells. The actin pattern was also examined in $\sec 3 \Delta N$, gic1 $1 \Delta i c 2 \Delta$ double mutant, and gic1 1 gic $2 \Delta \sec 3 \Delta N$ triple mutant. The actin organization in $\sec 3 \Delta N$ cells is polarized as expected (Additional file 1: Figure S1). Although the Gic proteins are required for actin cytoskeletal polarization, the polarized actin pattern is only slightly affected at non-restrictive temperature [26, 27]. Consistent with these results, we did not find apparent secretion defect in $\sec 3 \Delta N$ single mutant and gic $1 \Delta$ gic $2 \Delta$ double mutant at $25{ }^{\circ} \mathrm{C}$ (Fig. 4). Because the actin pattern in gic1 1 gic $2 \Delta \sec 3 \Delta N$ triple mutant is similar to gic $1 \Delta$ gic $2 \Delta$ double mutant at $25{ }^{\circ} \mathrm{C}$ (Additional file 1: Figure S1), the secretion defect in gic $1 \Delta g i c 2 \Delta \sec 3 \Delta N$ triple mutant would not be the outcome of disruption of polarized actin pattern.

We found that Gic2 is physically associated with exocyst complex. It is likely that its paralog, Gic1, may also interacts with this protein complex. However, it is unclear whether Gic proteins bind directly to one of the exocyst subunits, or bind to another protein which interacts with exocyst complex. Another exocyst subunit, Exo70, binds to both Cdc42 and PtdIns $(4,5) \mathrm{P}_{2}$ and regulates polarized secretion $[9,17,18,21]$. Because the binding of these two subunits with Cdc42 and PtdIns $(4,5)$ $\mathrm{P}_{2}$ are required for targeting of exocyst to bud tip, we wanted to know whether Gic proteins regulate polarized secretion through its binding with Exo70. However, we did not detect any physical interaction of Gic2 with Exo70 both in vivo and in vitro (data not shown). Further experiments are needed to explore the molecular mechanism of Gic proteins interacting with exocyst complex.

\section{Experimental procedures \\ Plasmids and yeast strains}

Standard methods were used for yeast growth and genetic manipulations [35]. All strains used in this project are listed in Additional file 4: Table S1. Yeast transformation was performed based on the lithium acetate method [36]. $2.5 \mathrm{~A}_{600}$ units of early log phase cells were collected in a $1.5-\mathrm{ml}$ centrifuge tube and washed once with $0.5 \mathrm{ml}$ of distilled water. $240 \mu \mathrm{l}$ PEG $3350(50 \% \mathrm{wt} / \mathrm{vol}), 36 \mu \mathrm{l}$ $1.0 \mathrm{M} \mathrm{LiAc}, 5 \mu \mathrm{l} 10 \mathrm{mg} / \mathrm{ml}$ sonicated salmon sperm DNA (Agilent Technologies), and 0.1-10 $\mu$ g DNA were added and the tube was vortexed until the cell pellet had been completely mixed. The cells were then shocked in a water bath at $42{ }^{\circ} \mathrm{C}$ for $20-25 \mathrm{~min} .2-200 \mu \mathrm{l}$ of the transformation mix was plated onto Petri dish plates containing 
solid synthetic complete medium. The plates were incubated at $25^{\circ} \mathrm{C}$ for $2-4$ days to recover transformants.

All mutagenesis was performed based on the pRS314CDC42 plasmid [37] using the QuickChange sitedirected mutagenesis kit (Stratagene, Inc.) and verified by sequencing. Different mutations were transformed into YEF1194 [37] and the transformants were later selected on SC-Trp-His plates with 5-FOA to lose the pRS316$H A-C D C 42$ plasmid balancer. The strains used in this study are listed in the strain table. Standard methods were used for yeast media and genetic manipulations.

\section{Light microscopy}

Chromosomal tagging of SEC5, SEC8, EXO70 and EXO84 by Green Fluorescence Protein (GFP) was performed as previously described [38]. Cells were grown to log phase at $25{ }^{\circ} \mathrm{C}$. The cells were then fixed for microscopy as described previously [39]. F-actin was stained with Alexa Fluor 488-conjugated phalloidin (Molecular Probes Corp.). Fluorescence microscopy was conducted with microscope CTR6000 (Leica) equipped with a PlanApochromat 100x, 1.40 NA oil immersion objective lens. Images were taken using LAS AF 1.5.1 acquisition software (Leica).

\section{Electron microscopy (EM)}

Cells were grown at $25^{\circ} \mathrm{C}$ in YPD media to log phase, and were then processed for thin section EM analysis using a Jeol-1010 transmission electron microscope. Cells for EM were collected by vacuum filtration using a $0.45 \mu \mathrm{m}$ nitrocellulose membrane and were fixed for $1 \mathrm{~h}$ at room temperature in fixation buffer ( $0.1 \mathrm{M}$ cacodylate, $\mathrm{pH}$ 7.4, $3 \%$ formaldehyde, $1 \mathrm{mM} \mathrm{MgCl}$, and $1 \mathrm{mM} \mathrm{CaCl}_{2}$ ). The cells were spheroplasted and fixed with $1 \%$ glutaraldehyde (in PBS, pH 7.4) at $4{ }^{\circ} \mathrm{C}$ overnight. The spheroplasts were washed in $0.1 \mathrm{M}$ cacodylate buffer and were postfixed twice with ice-cold $0.5 \% \mathrm{OsO} 4$ and $0.8 \%$ potassium for 10 min each. After dehydration and embedding in Spurr's epoxy resin (Polysciences, Inc.), thin sections were cut and transferred onto 600 mesh uncoated copper grids (Ernest Fullam, Inc.) and were post-stained with uranyl acetate and lead citrate. Cells were observed on a transmission electron microscope (Model 1010; JEOL) at $100,000 \times$ magnification.

\section{Secretion assays}

Analyses of the secretion of Bgl2 and invertase were carried out as previously described [40]. $20 \mathrm{ml}$ of yeast cells were grown to early log phase $\left(\mathrm{OD}_{600}\right.$ is $\left.0.6-1.0\right)$ at $25{ }^{\circ} \mathrm{C} . \mathrm{NaN}_{3}$ and $\mathrm{NaF}$ were added directly to the culture at a final concentration of $10 \mathrm{mM}$ each. $10 \mathrm{OD}_{600}$ units of cells were collected, washed with cell wash buffer (20 mM Tris- $\mathrm{HCl}, \mathrm{pH} 7.5,10 \mathrm{mM} \mathrm{NaN}_{3}$, and $10 \mathrm{mM}$
$\mathrm{NaF})$. The cells were resuspended in $300 \mu \mathrm{l}$ of spheroplast solution buffer $(50 \mathrm{mM}$ Tris- $\mathrm{HCl}, \mathrm{pH} 7.5,1.4 \mathrm{M}$ sorbitol, $10 \mathrm{mM} \mathrm{NaN}_{3}, 10 \mathrm{mM} \mathrm{NaF}, 30 \mathrm{mM}$ 2-Mercaptoethanol, and $0.2 \mathrm{mg} / \mathrm{ml}$ Zymolyase) and incubated at $37^{\circ} \mathrm{C}$ in a water bath for $30 \mathrm{~min}$. The spheroplasts were pelleted gently by centrifuge at $2000 \mathrm{rpm}$ for $5 \mathrm{~min}$ at $4{ }^{\circ} \mathrm{C} .100 \mu \mathrm{l}$ of supernatant was carefully transferred to a new tube and mixed with $20 \mu \mathrm{l}$ of $6 \times$ SDS loading buffer $(300 \mathrm{mM}$ Tris- $\mathrm{HCl}, \mathrm{pH}$ 6.8, $600 \mathrm{mM}$ dithiothreitol, $12 \%$ SDS, 0.6\% bromophenol blue, and $60 \%$ glycerol). This is the external pool. The remaining supernatant was removed and the pellet (spheroplasts) was washed once with $1 \mathrm{ml}$ of spheroplast wash buffer (50 mM Tris- $\mathrm{HCl}, \mathrm{pH} 7.5,1.4 \mathrm{M}$ sorbitol, $10 \mathrm{mM} \mathrm{NaN}_{3}$, and $10 \mathrm{mM} \mathrm{NaF}$ ) to remove residue external pool. The spheroplasts were dissolved in $300 \mu \mathrm{l}$ of lysate buffer $(20 \mathrm{mM}$ Tris-HCl, $\mathrm{pH}$ 7.5, $100 \mathrm{mM}$ $\mathrm{NaCl}, 2 \mathrm{mM} \mathrm{MgCl} 2,0.5 \%$ Triton X-100, and $1 \times$ protease inhibitor cocktail; Roche) by leaving on ice for $10 \mathrm{~min}$. The cell debris was removed after the sample was centrifuged at 13,000 rpm for $5 \mathrm{~min}$ at $4{ }^{\circ} \mathrm{C} .100 \mu \mathrm{l}$ of supernatant (lysates) was transferred to a new tube and mixed with $20 \mu \mathrm{l}$ of $6 \times$ SDS loading buffer. This is the internal pool. The internal pool and external pool samples were boiled at $95^{\circ} \mathrm{C}$ for $5 \mathrm{~min}$, loaded into 12\% SDSPAGE gel. $\mathrm{Bgl} 2$ was detected by Western blotting with an anti-Bgl2 rabbit polyclonal antibody (1:2000). For temperaturesensitive mutants, the cells were grown at $25^{\circ} \mathrm{C}$ or shifted to $37^{\circ} \mathrm{C}$ for $90 \mathrm{~min}$ before being processed for the Bgl2 assay.

Invertase secretion was examined as described previously [41]. $20 \mathrm{ml}$ of yeast cells were grown to early log phase $\left(\mathrm{OD}_{600}\right.$ is $\left.0.6-1.0\right)$ at $25^{\circ} \mathrm{C} .1 \mathrm{OD}$ cells were transferred to a new tube and washed with $1 \mathrm{ml}$ of ice cold $1 \mathrm{mM} \mathrm{NaN}$. The cells were then resuspended in $1 \mathrm{ml}$ YP plus glucose medium (1\% Bacto-yeast, 2\% Bactopeptone, and $0.1 \%$ glucose) and incubated at $25^{\circ} \mathrm{C}$ for $1 \mathrm{~h}$ to induce invertase expression. After $1 \mathrm{~h}$ of incubation, the cells were collected and washed once with $1 \mathrm{ml} 10 \mathrm{mM}$ $\mathrm{NaN}_{3}$. The cells were resuspended in $1 \mathrm{ml} 10 \mathrm{mM} \mathrm{NaN}_{3}$ and kept on ice. The external invertase was measured directly on the whole intact cells, whereas the internal invertase was measured after preparation of lysates. $0.5 \mathrm{ml}$ of cells were removed and mixed with $0.5 \mathrm{ml}$ of $2 \times$ spheroplast cocktail mix $(2.8 \mathrm{M}$ sorbitol, $0.1 \mathrm{M}$ Tris$\mathrm{HCl} \mathrm{pH} \mathrm{7.5,} 10 \mathrm{mM} \mathrm{NaN}_{3}, 0.4 \%$ 2-Mercaptoethanol, and $10 \mu \mathrm{g} / \mathrm{ml}$ Zymolyase-100T). The cells were incubated in water bath at $37{ }^{\circ} \mathrm{C}$ for $45 \mathrm{~min}$. The spheroplasts were collected and the supernatant was removed carefully without disturbing the pellet. The spheroplasts were dissolved at $4{ }^{\circ} \mathrm{C}$ in $0.5 \mathrm{ml} 0.5 \%$ Triton $\mathrm{X}-100$. The invertase assay was performed in $13 \times 100 \mathrm{~mm}$ tubes. $20 \mu \mathrm{l}$ of sample was placed in the tube and $80 \mu \mathrm{l}$ of $50 \mathrm{mM} \mathrm{NaAc}, \mathrm{pH}$ 5.1, was added. Then $25 \mu \mathrm{l}$ of $0.5 \mathrm{M}$ sucrose was added 
and the tube was incubated at $37^{\circ} \mathrm{C}$ for $30 \mathrm{~min} .150 \mu \mathrm{l}$ of $0.2 \mathrm{M} \mathrm{K}_{2} \mathrm{HPO}_{4}$ was added and the tube was placed on ice to stop the reaction. The sample was boiled for $3 \mathrm{~min}$ and put on ice. $1 \mathrm{ml}$ of assay mix was added ( $0.1 \mathrm{M} \mathrm{KPi} \mathrm{buffer,}$ $\mathrm{pH} 7.0,10 \mathrm{U} / \mathrm{ml}$ glucose oxidase, $2.5 \mu \mathrm{g} / \mathrm{ml}$ peroxidase, $150 \mu \mathrm{g} / \mathrm{ml} \mathrm{O}$-dianisidine, and $20 \mu \mathrm{M} \mathrm{N}$-Ethylmaleimide) and the sample was incubated at $37^{\circ} \mathrm{C}$ for $30 \mathrm{~min} .1 \mathrm{ml}$ of $6 \mathrm{~N} \mathrm{HCl}$ was added into the tube and the value of $\mathrm{A}_{540}$ was measured by the Spectrophotometer (SmartSpec 3000; Bio-Rad Laboratories). For temperature-sensitive mutants, the cells were grown at $25^{\circ} \mathrm{C}$ or shifted to $37^{\circ} \mathrm{C}$ for $90 \mathrm{~min}$ and then were grown in low-glucose medium ( $0.1 \%$ glucose) at the same temperature for $1 \mathrm{~h}$.

\section{In vitro binding assay}

Amino-terminus of Sec3 (a.a.71-241) and Gic2 (a.a.1155) were expressed as GST fusion proteins. Cdc42 and $c d c 42$ were expressed as $\mathrm{His}_{6}$-tagged fusion protein ( $\mathrm{His}_{6}-\mathrm{Cdc} 42$ or $\mathrm{His}_{6}-c d c 42$ ). $20 \mu \mathrm{g} \mathrm{Sec} 3$ (a.a.71-241) or Gic2 (a.a.1-155) and $10 \mu \mathrm{g}$ Cdc42 or $c d c 42$ mutant were used for in vitro binding assay as previously described [10].

\section{Whole cell extract preparation}

Yeast extracts were prepared using glass beads as described previously [42]. Yeast cells were grown to early log phase and collected by rapid centrifugation. The cell pellet was suspended in ice-cold lysis buffer $(50 \mathrm{mM}$ Tris-HCl, pH 7.5, $100 \mathrm{mM} \mathrm{NaCl}, 1 \mathrm{mM}$ EDTA, 1\% Triton $\mathrm{X}-100,5 \mathrm{mM} \mathrm{NaF}, 1 \mathrm{mM}$ sodium pyrophosphate, $1 \mathrm{mM}$ dithiothreitol, and $1 \times$ protease inhibitor cocktail; Roche). Glass beads (0.4-0.6 $\mathrm{mm}$ in diameter) were added into the resuspended cells. Cells were broken by vigorous vortexing at full speed for 8-10 cycles of 30-s vortexing followed by $30 \mathrm{~s}$ in an ice-water bath. The beads and cell debris were removed by centrifugation at $10,000 g$ at $4{ }^{\circ} \mathrm{C}$, and the supernatant was further clarified by centrifugation at $100,000 g$ at $4{ }^{\circ} \mathrm{C}$. The published Hot-SDS protein extraction protocol was used with slight modifications [43]. In brief, 50 A600 units of yeast cells were collected by centrifugation, washed once with water, and then suspended in $1 \mathrm{ml}$ of cold distilled water, followed by the addition of $1 \mathrm{ml}$ of $0.2 \mathrm{M} \mathrm{NaOH}$. Samples were mixed and incubated for $5 \mathrm{~min}$ at room temperature. Cells were collected by centrifugation, resuspended in $1 \mathrm{ml}$ of SDS sample buffer $(0.06 \mathrm{M}$ Tris- $\mathrm{HCl}, \mathrm{pH} 8.6,5 \%$ glycerol, $1 \%$ SDS, and $10 \mathrm{mM}$ 2-Mercaptoethanol) and boiled for 3-5 min. Samples were centrifuged, and protein concentrations were determined using the DC protein assay kit (Bio-Rad Laboratories).

\section{Immunoprecipitation}

For immunoprecipitation of GFP-tagged Sec5, total proteins were extracted by using the glass beads method [42]. A rabbit anti-GFP antibody was used for immunoprecipitation. Cell lysates were used for immunoprecipitation using protein $G$ beads and antiGFP antibody in immunoprecipitation buffer $(50 \mathrm{mM}$ Tris-HCl, pH 7.5, $150 \mathrm{mM} \mathrm{NaCl}, 1 \mathrm{mM}$ EDTA, $1 \mathrm{mM}$ EGTA, $10 \%$ glycerol, and $1 \times$ protease inhibitor; Roche) and $1 \times$ phosphatase inhibitor I (Roche) at $4{ }^{\circ} \mathrm{C}$ for $4 \mathrm{~h}$ with rotation. Beads were washed with washing buffer (50 mM Tris- $\mathrm{HCl}, \mathrm{pH}$ 7.5, $150 \mathrm{mM} \mathrm{NaCl}, 1$ mM EDTA, $1 \mathrm{mM}$ EGTA, and $10 \%$ glycerol) three times. The beads were mixed with $30 \mu \mathrm{l}$ of $1 \times$ SDS loading buffer and incubated at $95^{\circ} \mathrm{C}$ for $5 \mathrm{~min}$. Protein samples were then cooled on ice for several minutes and separated on $10 \%$ SDS-PAGE gel. Western blotting was performed using the anti-myc, anti-Sec8, Sec10 and Sec15 antibody. The Images were further processed using ImageJ software (National Institutes of Health).

\section{Additional files}

Additional file 1: Figure S1. Polarization of actin in gic $1 \Delta$ gic $2 \Delta \sec 3 \Delta \mathrm{W}$ mutant. Cells were grown to log phase at $25^{\circ} \mathrm{C}$, and then fixed. Actin was stained by Alexa Fluor 488-conjugated phalloidin. Scale bar, $5 \mu \mathrm{m}$. (B) Quantification of cells with polarized actin in each mutant. 90 cells were counted for each group $(n=3)$. Error bars represent standard deviations. The representative results from three independent experiments are shown.

Additional file 2: Figure S2. Structural integrity of the exocyst complex in the gic1 $\Delta$ gic $2 \Delta \sec 3 \Delta \mathrm{N}$ triple mutant. The exocyst component Sec5 in wild-type and mutant strains was GFP-tagged by chromosomal integration. The cells grown to log phase were incubated at $25^{\circ} \mathrm{C}$ or shifted to $37^{\circ} \mathrm{C}$ for $2 \mathrm{~h}$. The exocyst was immuno-isolated from the wild type and mutant cells by anti-GFP antibody, and individual exocyst components were detected by Western blot. At both $25^{\circ} \mathrm{C}$ and $37^{\circ} \mathrm{C}$, the exocyst components were coprecipitated with Sec5-GFP. Our result suggests that the assembly of the exocyst complex is largely unaffected in the gic $1 \Delta$ gic $2 \Delta s e c 3 \Delta N$ triple mutant. The representative results from three independent experiments are shown.

Additional file 3: Figure S3. The cdc42 mutants were not able to bind to Sec $3 \mathrm{~N}$ in vitro with either GDP or GTP in the binding buffer. GST fusion proteins containing (a.a.71-241) of Sec3 was purified and conjugated to glutathione Sepharose. Cdc42, cdc42-301, cdc42-302, cdc42-303, cdc42-304 and cdc42-305 were expressed as a Hisx6 fusion and purified from bacteria. The in vitro binding assay was performed using GST-Sec3 and Hisx6Cdc42 in the presence of GTPYS or GDP. The Hisx6-Cdc42 fusion protein bound to the GST-Sec3N Sepharose was detected by Western blotting with anti-Hisx6 antibody (bottom). Equal amounts of Sec3 fusion proteins on beads were used in the binding assay (middle; Ponceau $S$ staining). Equal amounts of cdc42 wild type and mutants were used (top, 1\% input, Western blotting with anti-Hisx6 antibody). The representative results from three different experiments are shown. The representative results from three independent experiments are shown.

Additional file 4: Table S1. Yeast strains and genotypes. Table S2. Plasmids used in this study. 


\section{Authors' contributions}

All authors conceived and designed the experiments; $Y L, T Z, D S$, and GL performed the experiments; $Y L, T Z$, and GL wrote the paper. All authors read and approved the final manuscript.

\section{Author details}

${ }^{1}$ Department of Biochemistry and Molecular Biology, China Medical University, Shenyang 110122, China. ${ }^{2}$ Institute of Translational Medicine, China Medical University, Shenyang 110122, China.

\section{Acknowledgements}

We thank Drs. Erfei Bi and Francis C. Luca for reagents and helpful suggestions. We are also very grateful to Jian Zhang, Xiaoyu Zhang and Tu Lu for help in the early phases of the project.

\section{Competing interests}

The authors declare that they have no competing interests.

\section{Availability of data and materials}

The data and materials used and/or analyzed during the current study are available from the corresponding author on reasonable request.

\section{Consent for publication}

Not applicable.

\section{Ethics approval and consent to participate}

Not applicable.

\section{Funding}

This work is supported by the National Natural Science Foundation of China (No. 31570819).

\section{Publisher's Note}

Springer Nature remains neutral with regard to jurisdictional claims in published maps and institutional affiliations.

\section{Received: 11 December 2018 Accepted: 29 March 2019} Published online: 04 April 2019

\section{References}

1. Park HO, Bi E. Central roles of small GTPases in the development of cell polarity in yeast and beyond. Microbiol Mol Biol Rev. 2007;71:48-96.

2. Perez P, Rincon SA. Rho GTPases: regulation of cell polarity and growth in yeasts. Biochem J. 2010;426:243-53.

3. Pruyne D, Legesse-Miller A, Gao L, Dong Y, Bretscher A. Mechanisms of polarized growth and organelle segregation in yeast. Annu Rev Cell Dev Biol. 2004;20:559-91.

4. Yamaguchi Y, Ota K, Ito T. A novel Cdc42-interacting domain of the yeast polarity establishment protein Bem1. Implications for modulation of mating pheromone signaling. J Biol Chem. 2007;282:29-38.

5. Adamo JE, Moskow JJ, Gladfelter AS, Viterbo D, Lew DJ, Brennwald PJ. Yeast Cdc42 functions at a late step in exocytosis, specifically during polarized growth of the emerging bud. J Cell Biol. 2001;155:581-92.

6. Wedlich-Soldner R, Altschuler S, Wu L, Li R. Spontaneous cell polarization through actomyosin-based delivery of the Cdc42 GTPase. Science. 2003;299:1231-5

7. Zhang X, Bi E, Novick P, Du L, Kozminski KG, Lipschutz JH, Guo W. Cdc42 interacts with the exocyst and regulates polarized secretion. J Biol Chem. 2001;276:46745-50.

8. Baek K, Knodler A, Lee SH, Zhang X, Orlando K, Zhang J, Foskett TJ, Guo W, Dominguez R. Structure-function study of the N-terminal domain of exocyst subunit Sec3. J Biol Chem. 2010;285:10424-33.

9. Wu H, Turner C, Gardner J, Temple B, Brennwald P. The Exo70 subunit of the exocyst is an effector for both $\mathrm{Cdc} 42$ and Rho3 function in polarized exocytosis. Mol Biol Cell. 2010;21:430-42.

10. Zhang X, Orlando K, He B, Xi F, Zhang J, Zajac A, Guo W. Membrane association and functional regulation of $\operatorname{Sec} 3$ by phospholipids and Cdc42. J Cell Biol. 2008;180:145-58.
11. He B, Guo W. The exocyst complex in polarized exocytosis. Curr Opin Cell Biol. 2009;21:537-42.

12. Heider MR, Munson M. Exorcising the exocyst complex. Traffic. 2012;13:898-907.

13. Jin Y, Sultana A, Gandhi P, Franklin E, Hamamoto S, Khan AR, Munson M, Schekman R, Weisman LS. Myosin V transports secretory vesicles via a Rab GTPase cascade and interaction with the exocyst complex. Dev Cell. 2011;21:1156-70.

14. Wu B, Guo W. The exocyst at a glance. J Cell Sci. 2015;128:2957-64.

15. Finger FP, Hughes TE, Novick P. Sec $3 p$ is a spatial landmark for polarized secretion in budding yeast. Cell. 1998;92:559-71.

16. Guo W, Tamanoi F, Novick P. Spatial regulation of the exocyst complex by Rho1 GTPase. Nat Cell Biol. 2001;3:353-60.

17. He B, Xi FG, Zhang J, TerBush D, Zhang XY, Guo W. Exo70p mediates the secretion of specific exocytic vesicles at early stages of the cell cycle for polarized cell growth. J Cell Biol. 2007;176:771-7.

18. He B, Xi F, Zhang X, Zhang J, Guo W. Exo70 interacts with phospholipids and mediates the targeting of the exocyst to the plasma membrane. EMBO J. 2007;26:4053-65.

19. Lipschutz $\mathrm{JH}$, Mostov KE. Exocytosis: the many masters of the exocyst. Curr Biol. 2002;12:R212-4.

20. Robinson NG, Guo L, Imai J, Toh-E A, Matsui Y, Tamanoi F. Rho3 of Saccharomyces cerevisiae, which regulates the actin cytoskeleton and exocytosis, is a GTPase which interacts with Myo2 and Exo70. Mol Cell Biol. 1999;19:3580-7.

21. Wu H, Rossi G, Brennwald P. The ghost in the machine: small GTPases as spatial regulators of exocytosis. Trends Cell Biol. 2008;18:397-404.

22. Boyd C, Hughes T, Pypaert M, Novick P. Vesicles carry most exocyst subunits to exocytic sites marked by the remaining two subunits, Sec3p and Exo70p. J Cell Biol. 2004;167:889-901.

23. Donovan KW, Bretscher A. Tracking individual secretory vesicles during exocytosis reveals an ordered and regulated process. J Cell Biol. 2015:210:181-9.

24. Luo G, Zhang J, Guo W. The role of Sec3p in secretory vesicle targeting and exocyst complex assembly. Mol Biol Cell. 2014;25:3813-22.

25. Mei K, Li Y, Wang S, Shao G, Ding Y, Luo G, Yue P, Liu J, Wang X, Dong M, Wang H, Guo W. Cryo-EM structure of the exocyst complex. Nat Struct Mol Biol. 2018;25:139-46.

26. Brown JL, Jaquenoud M, Gulli MP, Chant J, Peter M. Novel Cdc42binding proteins Gic1 and Gic2 control cell polarity in yeast. Genes Dev. 1997;11:2972-82

27. Chen GC, Kim YJ, Chan CS. The Cdc42 GTPase-associated proteins Gic1 and Gic2 are required for polarized cell growth in Saccharomyces cerevisiae. Genes Dev. 1997;11:2958-71.

28. Jaquenoud M, Peter M. Gic2p may link activated Cdc42p to components involved in actin polarization, including Bni1 p and Bud6p (Aip3p). Mol Cell Biol. 2000;20:6244-58.

29. Kawasaki R, Fujimura-Kamada K, Toi H, Kato H, Tanaka K. The upstream regulator, Rsr1p, and downstream effectors, Gic1p and Gic2p, of the Cdc42p small GTPase coordinately regulate initiation of budding in Saccharomyces cerevisiae. Genes Cells. 2003;8:235-50.

30. Orlando K, Zhang J, Zhang X, Yue P, Chiang T, Bi E, Guo W. Regulation of Gic2 localization and function by phosphatidylinositol 4,5-bisphosphate during the establishment of cell polarity in budding yeast. J Biol Chem. 2008;283:14205-12.

31. Harsay E, Bretscher A. Parallel secretory pathways to the cell surface in yeast. J Cell Biol. 1995;131:297-310.

32. Yamashita M, Kurokawa K, Sato Y, Yamagata A, Mimura H, Yoshikawa A, Sato K, Nakano A, Fukai S. Structural basis for the Rho- and phosphoinositide-dependent localization of the exocyst subunit Sec3. Nat Struct Mol Biol. 2010;17:180-6.

33. Orlando K, Sun X, Zhang J, Lu T, Yokomizo L, Wang P, Guo W. Exo-endocytic trafficking and the septin-based diffusion barrier are required for the maintenance of $\mathrm{Cdc42p}$ polarization during budding yeast asymmetric growth. Mol Biol Cell. 2011;22:624-33.

34. Cotteret $\mathrm{S}$, Chernoff J. The evolutionary history of effectors downstream of Cdc42 and Rac. Genome Biol. 2002;3: REVIEWS0002.

35. Sherman F. Getting started with yeast. Methods Enzymol. 2002;350:3-41.

36. Gietz D, St Jean A, Woods RA, Schiestl RH. Improved method for high efficiency transformation of intact yeast cells. Nucleic Acids Res. 1992;20:1425. 
37. Caviston JP, Tcheperegine SE, Bi E. Singularity in budding: a role for the evolutionarily conserved small GTPase Cdc42p. Proc Natl Acad Sci U S A 2002;99(19):12185-90.

38. Zhang X, Wang P, Gangar A, Zhang J, Brennwald P, TerBush D, Guo W. Lethal giant larvae proteins interact with the exocyst complex and are involved in polarized exocytosis. J Cell Biol. 2005;170:273-83.

39. Zajac A, Sun X, Zhang J, Guo W. Cyclical regulation of the exocyst and cell polarity determinants for polarized cell growth. Mol Biol Cell. 2005:16:1500-12.

40. Zhang X, Zajac A, Zhang J, Wang P, Li M, Murray J, TerBush D, Guo W. The critical role of Exo84p in the organization and polarized localization of the exocyst complex. J Biol Chem. 2005;280:20356-64.
41. Novick P, Field C, Schekman R. Identification of 23 complementation groups required for post-translational events in the yeast secretory pathway. Cell. 1980;21:205-15.

42. Inagaki M, Schmelzle T, Yamaguchi K, Irie K, Hall MN, Matsumoto K. PDK1 homologs activate the Pkc1-mitogen-activated protein kinase pathway in yeast. Mol Cell Biol. 1999;19:8344-52.

43. Kushnirov VV. Rapid and reliable protein extraction from yeast. Yeast. 2000;16:857-60.
Ready to submit your research? Choose BMC and benefit from:

- fast, convenient online submission

- thorough peer review by experienced researchers in your field

- rapid publication on acceptance

- support for research data, including large and complex data types

- gold Open Access which fosters wider collaboration and increased citations

- maximum visibility for your research: over $100 \mathrm{M}$ website views per year

At BMC, research is always in progress.

Learn more biomedcentral.com/submissions 